\title{
Copyright Transfer Agreements and Self-Archiving
}

\author{
Anita S. Coleman \\ University of Arizona \\ 1515 E. First St. \\ Tucson, AZ 85719 \\ +1 (520) 621-3565 \\ asc@u.arizona.edu
}

\author{
Cheryl Knott Malone \\ University of Arizona \\ 1515 E. First St. \\ Tucson, AZ 85719 \\ +1 (520) 621-3565 \\ ckmalone@u.arizona.edu
}

\begin{abstract}
Concerns about intellectual property rights are a significant barrier to the practice of scholarly self-archiving in institutional and other types of digital repositories. This introductory level, half-day tutorial will demystify the journal copyright transfer agreements (CTAs) that often are the source of these rights concerns of scholars. In addition, participants will be introduced to the deposit processes of self-archiving in an interdisciplinary repository and open access archive (OAA), such as DLIST, Digital Library for Information Science and Technology.
\end{abstract}

\section{Categories and Subject Descriptors}

J.7 [Computers in Other Systems]: Publishing.

\section{General Terms}

Legal Aspects.

\section{Keywords}

Open Access Archives, self-archiving, scholarly communication

\section{INTRODUCTION}

For more than three hundred years authors, publishers, and libraries have fulfilled specific niches and roles in the print scholarly communication cycle. In recent years, driven both by economics such as the rising prices of scholarly journals and the emergence of digital technologies, the traditional roles are undergoing a fundamental shift. Institutional and disciplinary repositories are also generally open access archives; i.e.; they are digital databases where authors can self-archive their works either before or after journal publication. Authors who practice selfarchiving by depositing their works in an open access archive of their choice make their works more easily and widely available to the WWW audience. While open access can help us find new funding and publishing models to alleviate the serials price crisis, it is more a value proposition that is in keeping with ideas such as increasing research "impact" and building the "intellectual commons". Also, the practice of self-archiving is not without its own problems: authors usually sign away their intellectual property rights at the time of article submission, having signed copyright away are unsure if they can self-archive, and deposit processes in digital repositories may seem time-consuming and difficult to the busy author creating new knowledge. But these problems can be easily surmounted as this tutorial will show.

\section{LEARNING OUTCOMES}

At the end of this tutorial, participants will be able to
1) Describe the scholarly communication cycle and the value of self-archiving as it relates to refereed journal publishing

2) Explain the role and potential value of open access archives in changing and improving the scholarly communication cycle

3) Identify and define the terms of journal CTAs

4 Seek a publisher's permission to deposit previous works published under restrictive CTAs

5) Modify journal CTAs to support self-archiving in an OAA

6) Become familiar with deposit and author-generated metadata processes for self-archiving

\section{TOPICS TO BE COVERED}

1) Scholarly communication cycle (including, digital repositories [1,2], open access movement [3] and open research tools [4], and intellectual property, including creative commons licenses [5])

2) Deciphering and modifying a CTA

3) Building the intellectual commons by self-archiving: Deposit and metadata processes

\section{ABOUT THE PRESENTERS}

Anita Sundaram Coleman received her Ph.D. in library and information science from the University of Illinois at UrbanaChampaign in 1996. Anita's research interests include the scholarly use of information. She is the founding editor of DLIST, Digital Library of Information Science and Technology, an open access archive and cross-institutional repository for the Information Sciences centering on cultural heritage institutions. Cheryl Knott Malone received her Ph.D. in library and information science from the University of Texas at Austin, also in 1996. Cheryl's research interests include access to information and the impact of differential access on groups and individuals. Cheryl is also a Founding Editor of DLIST.

\section{REFERENCES}

[1] DLIST. Digital Library for Information Science and Technology. <http://dlist.sir.arizona.edu $>$

[2] Harnad, S. For whom the gate tolls? $<$ http://www.ecs.soton.ac.uk/ harnad/Hypermail/Amsci/000 $0 . h t m l>$

[3] Suber, P. Open access news. $<$ http://www.earlham.edu/ peters/fos/fosblog.html $>$

[4] Research Support Tool $<$ http://www.pkp.ubc.ca/demos/rsttour/>

[5] Creative Commons $<\mathrm{http}: / /$ creativecommons.org/> 